\section{a \\ Iloss FAU U S P}

\section{THÁBATA REGINA DE SOUZA BRITO}

\section{CIBELE HADDAD}

TARALLI

NÍVEL DE PESQUISA

RESEARCH LEVEL

DOUTORADO

DOCTORATE

THÁBATA REGINA DE SOUZA BRITO

Doutoranda em Design pela

Universidade de São Paulo. Mestra em

Design Inovação e Sustentabilidade

pela Universidade do Estado de

Minas Gerais - UEMG e Designer de

Ambientes pela - UEMG. Professora

de Design de Interiores no Centro

Universitário UNA. Lecionou na Escola

de Design - UEMG e no Instituto

Federal de Educação, Ciência e

Tecnologia de Minas Gerais.

PhD student in Design from the

Universidade de São Paulo.

Master's in Design, Innovation and

Sustainability from the Universidade

do Estado de Minas Gerais - UEMG

and Environmental Designer at the

School of Design - UEMG. Professor of Interior Design at Centro Universitário

UNA. Taught at the Design School -

UEMG and at the Instituto Federal de

Educação, Ciência e Tecnologia de

Minas Gerais.

thabatabrito@usp.br

lattes.cnpq.br/

1738067592058379

\section{CIBELE HADDAD TARALLI}

Professora Doutora nos cursos de Arquitetura e Urbanismo e Design da Universidade de São Paulo. Orienta pesquisas em: metodologia e processos de pesquisa e de projeto; fabricação e montagem de produtos em design e arquitetura; linguagem e representação.

Professor of Architecture and Urbanism and Design at the University of São Paulo. Her research interests include methodology and processes of research and project; manufacturing and assembling products in design and architecture; language and representation.

cibelet@usp.br

lattes.cnpq.br/

6016190566941978

\title{
METODOLOGIA PARA PROJETOS - UMA PROPOSTA PARA O DESIGN DE INTERIORES
}

\author{
METHODOLOGY FOR PROJECTS - A PROPOSAL FOR \\ INTERIOR DESIGN
}

\section{PALAVRAS-CHAVE: DESIGN DE INTERIORES; ENSINO E PRÁTICA PROFISSIONAL; METODOLOGIA DE PROJETOS}

\section{KEYWORDS: INTERIOR DESIGN ; TEACHING AND PROFESSIONAL PRACTICE; PROJECT METHODOLOGY}

A pesquisa intenciona estudar os processos metodológicos projetuais do campo do Design de Interiores e sua eficácia no desenvolvimento dos projetos. A partir de uma investigação qualitativa, na modalidade de estudo de caso, complementada por estudo de reconhecimento, a respeito de concepções mais comumente endossadas e adotadas sobre o método de projeto especificamente ensinado e utilizado em práticas acadêmicas e profissionais do campo de design de interiores. O estudo compreenderá os aspectos conceituais, metodológicos, históricos, pedagógicos e de realidade profissional inerentes à especificidade do campo teórico e prático do design de interiores e, eventualmente, quando se fizer pertinente, também dos campos do design industrial e da arquitetura de interiores. A investigação se desenvolverá com base em levantamento "em loco" em cursos universitários tecnológicos e bacharelados selecionados em design de interiores e/ ou em design de ambientes e/ou em decoração, bem como em escritórios profissionais da área, em atividade nas regiões metropolitanas de Belo Horizonte e São Paulo através das perspectivas dos professores, alunos e profissionais com reconhecida experiência.

The research intends to study the processes of design methodology of the Interior Design field and its effectiveness in the development of the projects. Based on a qualitative case study, complemented by a recognition study, on the most commonly endorsed and adopted conceptions of the design method specifically taught and used in academic and professional practices in the field of interior design. The study will comprise the conceptual, methodological, historical, pedagogical and professional reality aspects inherent to the specificity of the theoretical and practical field of interior design and, where appropriate, also of the fields of industrial design and interior architecture. The research will be developed based on on-site surveys of selected technology and bachelor's degree courses in interior design and / or room design and / or decoration, as well as professional area offices active in the metropolitan regions of Belo Horizonte and São Paulo through the perspectives of teachers, students and professionals with recognized experience. 